\title{
Governmental Institutions as Agents of Change: Rethinking American Political Development in the Early Republic, 1787-1835*
}

During the past few years, a new generation of historians have turned their attention to the influence of law, public policy, and public administration in American life in the period between 1787 and 1835. The purpose of this essay is to highlight the contributions of these scholars in the hope that such an inquiry can further the ongoing interdisciplinary dialogue on American political development between historians, political scientists, and historical sociologists. It is not my intention to survey in an exhaustive fashion the existing body of historical writing on governmental institutions in the early republic or to compare this literature with related scholarship on other eras. Rather, I treat the period between 1787 and 1835 as a single epoch and consider its significance as a formative period in the history of American public life.

It would be misleading to assume that this new scholarship marks an entirely new departure in American historiography. The history of governmental institutions in the early American republic, after all, has long been a major concern of a distinguished galaxy of historians and political scientists that range from Henry Adams and Leonard D. White to Paul Wallace Gates

\footnotetext{
* Of the many individuals who have helped me sort out the ideas in this essay, I should like particularly to thank Andrew R. L. Cayton, Colleen A. Dunlavy, Robert P. Forbes, William J. Novak, Peter S. Onuf, Jack N. Rakove, Daniel Scott Smith, Benson Stein, Gordon S. Wood, Bertram Wyatt-Brown, Alfred F. Young, and two anonymous referees for Studies in American Political Development. None of these individuals, of course, are responsible for what I have done with their good advice. I am also indebted to Karen Orren for editorial suggestions that have improved the text. Earlier versions were presented at the Newberry Library's seminar in social history and at the Woodrow Wilson Center of the Smithsonian Institution. I am especially grateful to the Wilson Center for financial assistance in the preparation of an earlier draft.
} 
and Harry N. Scheiber. ${ }^{1}$ During the past few decades, however, revisionist historians and political scientists have questioned the importance that these scholars and the many who followed their lead assigned to these institutions. The first section below focuses on how and why these revisionists discounted the role of governmental institutions in the early republic. The second considers how a new generation of historians is reviving longneglected institutional themes, with a special focus on national public administration, state and local government, federalism, and the separation of powers. My thesis is that these younger historians share the insight that governmental institutions can be agents of change, and that this perspective can help frame a more realistic, coherent, and inclusive account of the American past.

The early republic has long been recognized as a formative era in American political development. No period in American history, writes Gordon S.

1. Henry Adams's most important historical writing is his History of the United States, 9 vols. (New York: Charles Scribner's Sons, 1889-1891), a survey of public administration during the presidencies of Thomas Jefferson and James Madison. Leonard D. White's principal works on governmental institutions in the early republic are The Federalists: A Study in Administrative History (New York: Macmillan Co., 1948); The Jeffersonians: A Study in Administrative History, 1801-1829 (New York: Macmillan Co., 1951); and The Jacksonians: A Study in Administrative History, 1829-1861 (New York: Macmillan Co., 1954). For an overview of White's contribution to American historical writing, see Richard R. John, "Leonard D. White and the Invention of American Administrative History," Reviews in American History 24 (June 1996): 344-60.

Paul Wallace Gates's major works include The Farmers's Age: Agriculture, 1815-1860 (New York: Holt, Rinehart, and Winston, 1960), and History of Public Land Law Development (Washington, D.C.: Government Printing Office, 1968). Several of Gates's essays have been brought together in The Jeffersonian Dream: Studies in the History of American Land Policy and Development, ed. Allan G. Bogue and Margaret Beattie Bogue (Albuquerque, N.M.: University of New Mexico Press, 1996). For a sampling of the work of Gates's students, see David M. Ellis, et al. eds., The Frontier in American Economic Development: Essays in Honor of Paul Wallace Gates (Ithaca, N.Y.: Cornell Lniversity Press, 1969). For an introduction to Gates's legacy, see Bogue and Bogue, "Introduction," ix-xx, and Harry N. Scheiber, "The Economic Historian as Realist and as Keeper of Democratic Ideals: Paul Wallace Gates's Studies of American Land Policy," Journal of Economic History 40 (September 1980): 585-93. Recent works that build on Gates's legacy include Stephen Aron, How the West Was Lost: The Transformation of Kenturky from Daniel Boone to Henry Clay (Baltimore, Md.: Johns Hopkins University Press, 1996); Alan Taylor, Liberty Men and Great Proprietors: The Revolutionary Settlement on the Maine Frontier, 1760-1820 (Chapel Hill: University of North Carolina Press, 1990); and id., William Cooper's Towon: Power and Persuasion on the Frontier of the Early American Republic (New York: Alfred A. Knopf, 1995).

Harry N. Scheiber's publications include Ohio Canal Era: A Case Siudy of Government and the Economy; 1820-1861, 2d ed (1968; Athens, Ohio: Ohio University Press, 1987); "The Road to Munn: Eminent Domain and the Concept of Public Purpose in the State Courts," Perspectives in American History 5 (1971): 329-402; "Property Law, Expropriation, and Resource Allocation by Government: The United States, 1789-1910," Journal of Eronomic History 33 (March 1973): 23251; "Federalism and the American Economic Order, 1789-1910," Law and Soriety Reriew 10 (Fall 1975) : 57-118; "American Constitutional History and the New' Legal History: Complementary Themes in Two Modes," Journal of American History 68 (September 1981): 337-50; "Regulation, Property Rights, and the Definition of 'The Market': Law' and the American Economy," Journal of Economic History 41 (March 1981): 103-11; and "Public Rights and the Rule of Law in American Legal History," California Law Review 72 (March 1984): 217-51. 
Wood, in a recent historiographical survey, witnessed more "headline events," giving political history an "overriding influence" in most scholarly accounts. ${ }^{2}$ During these years, public figures invented the mass party, hastened the creation of a national economy, and established many of the governmental institutions that remain important today. Each of these developments helped to give the period its distinctive character, as did the many enduring political writings of contemporaries.

Yet even though - or, perhaps, because - the early republic is so familiar, it is often misunderstood. It has, for example, become customary for scholars to contend that the central government sank into relative insignificance following the defeat of the Federalists in the election of 1800; that the polity between 1800 and 1828 is adequately characterized as a state of courts and parties"; and that the rise of the Jacksonian party in the election of 1828 was a product of more fundamental changes originating in the wider society outside of the political realm. Each of these assertions is challenged by the recent scholarship this essay surveys.

The neglect of governmental institutions by historians of the early republic followed logically from the premises of two related, yet distinct, traditions within American historiography: the "new" social history, with its preoccupation with ordinary people; and the "new" political history, with its focus on electoral behavior. ${ }^{3}$ In addition, it drew on the widely shared conviction that major political developments, including those involving governmental institutions, were best understood as the product of antecedent social causes.

The central project of the new social history, at least as it has been practiced in the United States, has been the recovery of the lived experiences of previously neglected groups such as blacks, women, and the poor. Its leading practitioners hoped to move beyond the study of political phenomena, which they typically dismissed as superficial and ephemeral, and to write American history "from the bottom up." ${ }^{4}$ Historians writing from

2. Gordon S. Wood, "The Significance of the Early Republic," Journal of the Early Republic 8 (Spring 1988): 4.

3. Other historiographical traditions that neglect the role of governmental institutions include the "new" economic history and modernization theory. The new economic history, whose leading practitioners include Robert William Fogel and Douglass C. North, once regarded law, public policy, and public administration as irrelevant to the study of market rationality and economic growth. Recently, however, both Fogel and North have turned their attention to governmental institutions. See, for example, Robert William Fogel, Without Consent or Contract: The Rise and Fall of American Slavery (New York: W. W. Norton \& Co., 1989); and Douglass C. North, Institutions, Institutional Change, and Economic Performance (New York: Cambridge University Press, 1990). The best known application of modernization theory to the history of the period is Richard D. Brown, Modernization: The Transformation of American Life, 1600-1865 (New York: Hill and Wang, 1976). Though Brown touched on institutional developments, particularly in communications, he was ultimately more concerned with changing modes of cultural expression. For a critique, see James A. Henretta, "Modernization': Toward a False Synthesis," Revieus in American History 5 (December 1977): 445-52.

4. Useful introductions to the new social history include Alice Kessler-Harris, "Social History," in The New American History, ed. Eric Foner (Philadelphia: Temple University Press, 1990), 163-84; Peter N. Sterns, "Toward a Wider Vision: Trends in Social History," in The Past Before Us: 
this perspective, as one astute chronicler of the new social history has observed, "assume that political decisions affect social existence" yet "emphasize the degree to which the social system shapes the character of political institutions." ${ }^{5}$ All held, either explicitly or implicitly, that society rather than the polity or the culture - was the most appropriate unit of analysis. When they turned their attention to courts, legislatures or administrative bodies, they focused less on their social effects than on their embeddedness in the broader environment. Fewer still accorded major political events, such as the framing of the federal Constitution or the establishment of state or central governments, an independent role as agents of change. None assigned much causal significance to structural features of the American polity, such as federalism or the separation of powers. By focusing on behavior and social relations - as Robert F. Berkhofer, Jr., explained - the new social historians affirmed their faith in the concept of society as the "key to understanding the structure of American history." 6

The new social historians' understanding of the relationship between politics and social change had an unmistakable affinity with the behavioralist methodology so influential among political scientists and sociologists during the 1960s and 1970s. This was true even though, at the time, the relationship between the new social history and behavioralism was far from self-evident. Few new social historians shared the behavioralists' confidence in quantification, and many rebelled against the behavioralists' preoccupation with equilibrium models of social change. Yet both treated political events as the reaction of social groups to behavioral stimuli; both assumed that the public sphere was little more than the arena in which various social groups jostled for advantage; and both took more-or-less for granted the existence of this public sphere, as well as the coherence of the society over which it presided.

Emblematic of the new social historians' approach to the relationship of politics and social change was Paul Johnson's Shopkeeper's Millennium, an imaginative and frequently cited study of religious revivalism in upstate New York. Like many new social historians, Johnson traced the origins of political conflict to the local community, an approach nicely revealed by his handling of the Sabbath mails controversy, a major national political issue during the 1820s. From Johnson's perspective, this issue had little intrinsic

Contemporary Historical Writing in the United States, ed. Michael Kammen (Ithaca, N.Y.: Cornell University Press, 1980), 205-30; and James A. Henretta, "Social History as Lived and Written," American Historical Review 84 (December 1979): 1293-322.

5. James A. Henretta, "Comment," American Historical Review 84 (December 1979): 1331.

6. Robert F. Berkhofer, "Comment," American Historical Review 84 (December 1979): 1326. For a related discussion that focused specifically on the colonial period, see Joyce Appleby, "A Different Kind of Independence: The Postwar Restructuring of the Historical Study of Early America," William and Mary Quarterly 3d ser., 50 (April 1993): 245-67. Appleby's theme was the centrality of the concept of society to recent scholarship on colonial America. "Investing the typical conditions of everyday existence with an importance they had never known before," Appleby wrote, "historians made society - its geographic setting, its enduring traditions, its productive and reproductive activities - the central focus of historical research" (ibid., 250). 
significance. Merchants opposed the transportation of the mail on the Sabbath not because of genuine moral qualms, but because strict Sabbath observance helped force unruly artisans to adopt middle-class ways. That the causal arrows might be reversed - and that the Sabbatarian protest might have been prompted by extra-local circumstances that forced a confrontation at the local level - was a possibility that Johnson did not feel necessary to explore in any detail. ${ }^{7}$

Equally dismissive in their approach toward governmental institutions were the leading practitioners of the new political history, also sometimes called the ethnocultural school. Like new social historians, ethnoculturalists sought to write American history from the standpoint of ordinary people. The lived experiences of the rank-and-file, or so they assumed, held the key to explaining events once mistakenly ascribed to the machinations of elites. No longer would political accounts remain preoccupied with law, public policy, and public administration, or revolve around the deliberations of generals, diplomats, judges, and public administrators.

To hasten this reorientation, new political historians focused on the electoral process. In the early republic, a large percentage of Americans including the overwhelming majority of white adult men - had the right to vote. Voting, in fact, could plausibly be described as the only political activity that routinely involved a sizable fraction of the population. By statistically correlating electoral data with a variety of social indicators such as religion, ethnicity, or wealth, new political historians hoped to explain not only why Americans voted as they did, but also what they believed, on the assumption that electoral data was one of the few sources of information about the main currents of American culture. ${ }^{8}$ To interpret the polling data, new political historians relied on highly sophisticated quantitative techniques and imported from behavioralistic political scientists the assumption that social circumstances held the key to political change.

The most notable conclusion to emerge from the new political historians' research was their discovery that cultural indicators such as ethnic background or religious affiliation were more likely to be correlated with voting data than economic indicators such as wealth. A few new political historians, to be sure, remained convinced that, at least in certain elections, economic issues loomed uppermost. This was particularly true in elections

7. Paul E. Johnson, A Shopkeeper's Millennium: Society and Revivals in Rochester, New York, 1815-1837 (New York: Hill and Wang, 1978), 83-88. For a critique, see Richard R. John, Spreading the Newus: The American Postal System from Franklin to Morse (Cambridge, Mass.: Harvard University Press, 1995), chap. 5, esp. 324 n.55, 326 n.86.

8. Surveys of the new political history include Richard J. Jensen, "Historiography of American Political History," in Encylopedia of American Political History (New York: Charles Scribner's Sons, 1984), ed. Jack P. Greene, 1-25; and Allan G. Bogue, "The New Political History in the 1970s," in Past Before Us, 231-51. For a recent update, see Ronald P. Formisano, "The Invention of the Ethnocultural Interpretation," American Historical Review 99 (April 1994): 453-77.

The assumption that political history is a branch of social history has become so widespread that at least one political historian felt it incumbent to remind his readers that his monograph was not a work of social history. Andrew R. L. Cayton, The Frontier Republic: Ideology and Politics in the Ohio Country, 1780-1825 (Kent, Ohio: Kent State University Press, 1986), 185. 


\section{RICHARD R. JOHN}

that followed major economic downturns, such as the election of 1840 , which began shortly following the Panic of $1837 .{ }^{9}$ But most concluded that, for the bulk of the electorate, cultural issues were the overriding concern. Political insiders might pay close attention to where a candidate stood on banking or internal improvements. Ordinary voters, however, were more likely to be swayed by a candidate's position on sabbatarianism or temperance. A skeptic might conclude that the electorate rarely exerted much influence on public policy, since cultural questions only rarely came up for debate and almost never dominated the legislative agenda. But most new political historians contented themselves with exploring the kaleidoscopic array of cultural concerns that agitated ordinary Americans at the grass roots.

Given the new political historians' preoccupation with the social basis of electoral behavior, it is not surprising that they devoted little attention to law, public policy, or public administration. Consider, for example, Ronald P. Formisano's Transformation of Political Culture, a detailed study of political change in Massachusetts in the half century following the framing of the federal Constitution. Formisano was by no means oblivious to the role of governmental institutions in American life: indeed, he was among the first historians to link government-supported innovations in transportation and communications with the rise of the mass party. "Amid many kinds of changes," he wrote, "those associated with what historians have called the transportation and communications 'revolutions' probably did the most to create the technical potential for mass political organizations." 10 Yet Formisano's primary concern was not governance, but, rather, the dramatic increase in popular interest in national politics that historians have long associated with the ascendancy of the Jacksonians in the 1820s. Formisano demonstrated convincingly that this development owed less to party behavior than many historians had previously assumed. In certain settings, Formisano conceded, the organizational efforts of party leaders might have some independent effect on voting levels. For the most part, however, political parties were a "dependent variable" shaped in the short run by political events and in the long run by changing social circumstances and communications technology. ${ }^{11}$

Because Formisano's subject was the political party, he, quite understandably, did not find it incumbent to consider these other phenomena in any detail. Still, his study did help to redirect scholarship on the early republic away from parties and toward a range of topics that recent political historians have neglected. After all, as he persuasively demonstrated, in

9. Michael F. Holt, "The Election of 1840, Voter Mobilization, and the Emergence of the Second American Party System: A Reappraisal of Jacksonian Voting Behavior," in A Master's Due: Essays in Honor of David Herbert Donald, ed. William J. Cooper, Jr., Michael F. Holt, and John McCardell (Baton Rouge: Louisiana State University Press, 1985), 16-58. For a critique, see Ronald P. Formisano, "The New Political History and the Election of 1840," Journal of Interdisciplinary History 23 (Spring 1993): 661-82.

10. Ronald P. Formisano, The Transformation of Political Culture: Massachusetts Parties, 1790s-1840s (New York: Oxford Lniversity Press, 1983), 16.

11. Ibid., 41. 
this period parties played little direct role in shaping either public policy or the distribution of wealth. ${ }^{12}$

The new political historians' neglect of public policy prompted criticism even from historians broadly sympathetic to their approach. Historians who confined themselves to the study of voting patterns, declared Richard L. McCormick, in a judicious survey of scholarship in this vein, solved, at most, only half the puzzle. This was because, in the early republic, parties were not "responsible" bodies whose organizers sought to enact legislation that reflected their public positions on the major issues of the day. Rather, they were electoral machines dedicated to securing public office and the perquisites of power. What did it matter, McCormick mused, if the electorate was more frequently influenced by cultural than economic appeals? How did this explain what the government did? 13

McCormick urged political historians to shift their angle of vision from elections to policymaking and to make their primary theme the study of governance. This McCormick understood to embrace not only the framing of public policy and the rules and procedures for "getting and using the power of the state," but also the popular expectations that Americans held about what government ought to do. ${ }^{14}$ The "motive force" behind political change in the nineteenth-century United States, McCormick speculated, might well be the prior emergence of a "new vision of government," a conclusion of the "first importance." 15 To advance this debate, there was an "urgent need for a satisfactory typology of governmental policies, for new methods of describing and categorizing those policies, and for new ways of identifying the significant governmental transformations in American history." The study of governance, McCormick hoped, might in this way become as systematic as the study of elections. ${ }^{16}$

McCormick's critique raised the intriguing possibility that governmental institutions might be as significant as social circumstances in explaining how American politics evolved. But, like the new political historians, he found this notion problematic. Government might be central to the political process, McCormick conceded, yet public policy still derived "fundamentally" from the social setting, rather than from past politics or institutional arrangements. ${ }^{17}$ Nowhere was this more true than in the early republic, when public policy was "little more than the accumulation of isolated, individual choices, usually of a distributive nature." 18 This was even true, McCormick added, in those states that experimented with economic planning in the transportation sector, since these projects ultimately fell victim to sectional rivalry and interest-group competition. Only later,

12. Ibid., 316-20, 342.

13. Richard L. McCormick, The Party Period and Public Policy: American Politics from the Age of Jackson to the Progressize Era (New York: Oxford University Press, 1986), 14-15. "The most important message conveyed by ethnocultural analysis," McCormick wrote, "is not that voters were ethnically and religiously motivated, but that grass-roots concerns are so irrelevant to public policymaking" (ibid., 56).

14. Ibid., 18. 15. Ibid., 131-32. 16. Ibid., 87.

17. Ibid., 19. 18. Ibid., 206. 


\section{RICHARD R. JOHN}

well after the Civil War, would public policy assume a more coherent and programmatic form. ${ }^{19}$

Joining the new social and political historians in downplaying governmental institutions in the early republic were many historians who resisted being identified with these traditions, but who adopted a similar approach to the relationship between politics and social change. Of these, few have proved more influential than social historians Oscar and Mary Flug Handlin and political scientist Louis Hartz. In the 1940s, both the Handlins and Hartz published major studies of nineteenth-century economic policy in Massachusetts and Pennsylvania, respectively, that buttressed the idea that the major political developments in the early republic were best understood as products of antecedent social causes.

It has long been recognized that the Handlins and Hartz - and also the Social Science Research Council (SSRC), which subsidized their research intended their studies to help legitimize the major expansion of government economic involvement that accompanied the New Deal. The Handlins and Hartz predicated their research on the assumption that previous studies of nineteenth-century government economic policy had mistakenly concentrated on the federal government, overlooking the far more important promotional activities that governmental institutions had performed in the individual states. By increasing public awareness of these activities, the SSRC hoped to document the existence in the distant American past of a rationale for New Deal-inspired public works projects such as the Tennessee Valley Authority. In a memorandum on the SSRC project, Herbert Heaton observed that it was felt desirable to destroy, if possible, the

popular notion that until the fourth of March, 1933, the United States was
the land of laissez faire, and the alternate notion that governments, when they
have acted, have done so only in a regulatory capacity. Historians know that
both these notions are fantastically untrue; yet the story of the role of govern-

19. McCormick borrowed the concept of distributive politics from a well known typology that political scientist Theodore J. Lowi devised in 1964 (ibid., 204). Prior to 1890, Lowi declared, the distribution of resources by the government was "almost the exclusive type" of national domestic policy. After 1890, Lowi added, regulation and redistribution also became important. Theodore J. Lowi, "American Business, Public Policy, Case-Studies, and Political Theory," World Politics 16 (July 1964): 689.

Lowi's characterization of American public policy in the period before 1890 complements the well known thesis of legal historian Willard Hurst that legal rule-making in this period was fragmented, opportunistic, and market-driven. On this point, see Harry N. Scheiber, "Public Economic Policy and the American Legal System: Historical Perspectives," Wisconsin Law Review (1980): 1184-85, and "At the Borderland of Law and Economic History: The Contributions of Willard Hurst," American Historical Review 75 (February 1970): 753. Scheiber's own interpretation of nineteenth-century legal doctrine highlighted the centrality of a distinctive "public rights" tradition that was distinct not only from the legal instrumentalism of Hurst - and, more recently, Morton J. Horwitz - but also from the rights-based jurisprudence of Edward S. Corwin. Scheiber, "American Constitutional History and the New Legal History," 347. See also Molly Selvin, "The Public Trust Doctrine in American Law and Economic Policy, 1789-1920," Wisconsin Law Review (1980): 1403-42. 
ments in American economic enterprise has not been adequately studied and presented. ${ }^{20}$

The SSRC was intent upon challenging the myth of laissez-faire and the Handlins and Hartz obliged. In neither Massachusetts nor Pennsylvania, they concluded, had laissez-faire gained many adherents in the period prior to the Civil War.

Their studies, along with the related works they spawned, helped to persuade many historians of the persistence, well into the nineteenth century, of an activist tradition of government involvement in the economic realm. ${ }^{21}$ What is less well understood is the extent to which their work encouraged later historians to discount the influence of governmental institutions in the nineteenth-century United States. To understand this admittedly puzzling turn of events, it is helpful to review briefly what the Handlins and Hartz did and did not contend.

The Handlins' Commonwealth: A Study of the Role of Government in the American Economy: Massachusetts, 1774-1861 traced the main currents of public opinion toward economic policymaking in Massachusetts from the American Revolution to the Civil War. Their subject, as they explained in the preface to a revised edition, was less the workings of specific governmental institutions than the "aspirations and intentions of the people of the state." In the early republic, they observed, the people of Massachusetts retained an allegiance to a seventeenth-century commonwealth ideal that empowered public authorities to undertake a wide variety of tasks. This ideal received fresh impetus from the American Revolution, which encouraged the citizenry of the newly established commonwealth of Massachusetts to embrace a "vigorous conception of the state."22 For the next few decades, policymakers closely regulated the chartering of corporations and promoted a host of commercial undertakings that it assumed to serve the public good. By mid-century, however, as the number of individuals and groups who sought promotional opportunities multiplied, policymakers found them increasingly hard to justify. The commonwealth ideal, in effect, fell victim to its own success, and was eventually supplanted by a more purely regulatory, less overtly promotional, yet not necessarily less activist vision, which the Handlins' termed liberalism to highlight its affinities with popular currents of humanitarian reform. ${ }^{23}$ Though this liberal vision ex-

20. Herbert Heaton, "General Memorandum . . .," in Oscar Handlin and Mary Flug Handlin, Commonwealth: A Study of the Role of Government in the American Economy: Massachusetts, 17741861, rev. ed. (1947; Cambridge, Mass.: Belknap Press of Harvard University Press, 1969), 270.

21. For a survey of the scholarship fostered by the SSRC project, see Harry N. Scheiber, "Government and the Economy: Studies of the 'Commonwealth' Policy in Nineteenth-Century America," Journal of Interdisciplinary History 3 (Summer 1972): 135-51.

22. Handlin and Handlin, Commonwealth, xiv, xvii.

23. Ibid., 224, 228, 243. It is worth noting that at no point in Commonwealth did the Handlins explicitly term the nineteenth-century polity a "liberal state." Rather, they called it a "humanitarian police state," a "reform state," or a "regulatory police state" (ibid., 203, 229, 242). Later historians, however, settled on the liberal state tag - picking up, no doubt, on the 


\section{RICHARD R. JOHN}

tended the role of the state in protecting individual rights, it limited its ability to shape the course of economic development.

Hartz told a similar story, but with a greater sensitivity to the institutional setting. Hartz's main theme was the rise and fall of the theory of "mixed enterprise," a once ubiquitous quasi-public, quasi-private rationale for canals, railroads, and other large-scale public work projects. "Though I have not hesitated to explore relevant institutional problems at length," he conceded, "I have been centrally concerned with this theory [of mixed enterprise] - the struggles out of which it arose, the doctrinal techniques by which it was perfected, the opposing ideas which served to undermine it, even the reasons why we in our own time have, as I believe, often failed to grasp its importance." ${ }^{4}$ Not until the 1840 s would critics attack the theory of mixed enterprise in a principled way, and, even then, they refrained from articulating a full-blown defense of laissez-faire, which would come only after the Civil War.

Hartz was much impressed by the scale of these short-lived government ventures:

Nothing in the economic policy of the colonial period could compare in magnitude with the public works program; nothing in its regulatory policy could compare with the immense variety of regulatory controls involved in corporate regulation. . . . In the public investment area the state was pioneering enterprises distinctly in advance of private effort; we can scarcely blame the state if the canals which it built were soon made obsolete by the emergence of the railroad age. ${ }^{25}$

Yet he devoted far less attention to the rise of the mixed-enterprise ideal than to its demise. In large measure, one suspects, this was because Hartz considered it more important to explain why these projects were so soon forgotten - and, thus, unavailable as precedents for New Deal era ventures such as the Tennessee Valley Authority - than to consider how they distinguished the American polity in the early republic from the colonial polity that it supplanted.

Neither the Handlins nor Hartz neglected the social setting in which public policy was framed. Both, after all, pointed to social circumstances in explaining why an activist vision of state power proved impossible to sustain. Yet they displayed relatively little interest in the government's social effects. ${ }^{26}$ The Handlins readily conceded the limitations of their study in this regard. "We did not," they declared, "venture to assess the effects of government action upon economic trends." It would have been useful they later conceded, in looking back upon their work - "to add an analysis of whether the effects then perceived were actual or imagined." Still, they

Handlins's brief but suggestive reference to liberalism - and for this reason it is highlighted here.

24. Louis Hartz, Economic Policy and Democratic Thought: Pennsylvania, 1776-1860 (Cambridge, Mass.: Harvard University Press, 1948), xi.

25. Ibid., 294-95.

26. This point is made in Morton J. Horwitz, The Transformation of American Law, 1780-1860 (Cambridge, Mass.: Harvard University Press, 1977), xiv. 
were quick to add, the absence of such an analysis did nothing to diminish the accuracy of their description of what the people of Massachusetts thought they saw during the period under review. ${ }^{27}$ If contemporaries believed a particular public policy to be in the public interest, the Handlins saw little reason to question their judgment.

Hartz, to be sure, was highly sensitive to the extent to which publicspirited rhetoric might conceal outcomes that were decidedly partial in their results. "Not only did all institutional efforts to lend expression to the Will of the People become enmeshed in party, sectional, and interest-group mechanics," but many such efforts were intentionally designed to block the government from taking positive action: "It was in the realm of administration, more clearly than anywhere else, that the age was misled by the glamour of its democratic dreams." 28 Yet Hartz, too, devoted more care to describing the main contours of the theory of mixed enterprise than to explaining how the Pennsylvania government shaped nineteenth-century American life.

Given the preoccupation of the Handlins and Hartz with cultural perceptions and their focus on promotional ventures that proved short-lived, it is perhaps not surprising that later historians often drew on their work to support the claim that government involvement in the nineteenth-century American economy was easily exaggerated. ${ }^{29}$ Both, after all, traced the fall of a vision that promoted public involvement in economic development and constrained private power, and the rise of an alternative - and, in some ways, opposing - vision that limited government intervention and encouraged private power. ${ }^{30}$ And both explained this transition by pointing to large-scale social processes originating in the wider society, rather than to

27. Handlin and Handlin, Commonwealth, xvi, xiv.

28. Hartz, Economic Policy and Democratic Thought, 32-33.

29. It was partly for this reason, speculated legal historian William J. Novak, that the commonwealth and mixed-enterprise studies have failed to challenge the "fundamentally liberal-capitalist portrait of nineteenth-century America." Novak, The People's Welfare: Law and Regulation in Nineteenth-Century America (Chapel Hill: University of North Carolina Press, 1996), 284 n.6. Of the scholars who have produced studies in the commonwealth tradition, only Scheiber has challenged the primacy of instrumentalist considerations in the shaping of nineteenth-century American law.

30. Scheiber, "Government and the Economy," 144. See also Robert A. Lively, "The American System: A Review Article," Business History Review 29 (March 1955): 81-96. The Handlins and Hartz, Lively noted, "instead of eliminating the laissez-faire theme from analysis of public policy ... merely changed its chronology. Each assumed general adherence to the philosophy after the mid-century point at which their studies ended. ... The authors set out to describe what the people of Massachusetts and Pennsylvania conceived to be the role of their governments, rather than to outline government activity; and with this definition of their work as exercises in intellectual history, they very often relegated principal economic themes to the position of supporting detail" (ibid., 82-84).

Lively exaggerated when he termed the Handlins' and Hartz's studies "exercises in intellectual history." He was closer to the mark when he faulted them for treating government economic activism as episodic. For a view that stresses the continuity in government economic policymaking throughout much of the nineteenth century, see George H. Miller, Railroads and the Granger Laws (Madison, Wisc.: University of Wisconsin Press, 1971). See also Harry N. Scheiber, "Public Policy, Constitutional Principle, and the Granger Laws: A Revised Historical Perspective," Stanford Law Review 23 (1970-1971): 1029-37. 


\section{8}

RICHARD R. JOHN

prior institutional arrangements or the decisions of administrators, policymakers, and other elites.

Equally influential in this regard were their synthetic overviews of American political development - the Handlins' Dimensions of Liberty, and Hartz's Liberal Tradition in America - that traced the roots of American politics to circumstances in the wider society. ${ }^{31}$

Among the first historians to adopt the Handlin-Hartz approach to American political development was Bernard Bailyn, one of Oscar Handlin's first students at Harvard. Like the Handlins and Hartz, Bailyn was ultimately less concerned with what the state did than with how influential contemporaries conceived of it. This was evident in the sweeping contrast he drew between the expansive domain of the seventeenth-century British imperial polity and the limited mandate of the nineteenth-century American liberal state. In the eighteenth century, Bailyn contended, the social circumstances of British North America - including, above all, the availability of enormous amounts of land - emboldened provincial assemblies to perform a range of tasks far greater than the British Parliament or the colonial magistrates. ${ }^{32}$ How, then, Bailyn wondered, did this strong eighteenthcentury state became the weak state that the Handlins described?

The "Alienation of the State," Bailyn posited, was well underway by 1760 and greatly accelerated in the years immediately preceding the outbreak of the American Revolution. ${ }^{33}$ Disturbed by the recent expansion of the British state and sensitive to the gap between the broad powers colonial magistrates presumed to exercise and the limited scope of their actual authority, colonists rejected the notion that governmental institutions could be instruments of the public good. This rejection, in turn, became a key feature of the American political tradition, which, Bailyn suggested, has always denied that governmental institutions could act independently of the individuals over whom they presided. Bailyn's principal interest - observed Jack N. Rakove, in a perceptive essay on Bailyn's oeuvre - was not the effects of state power but, rather, the "weakening" of its authority and its inability to define and advance "transcendent notions of the public good" that were distinct from those sought by particular interests within the society. The "liberal state of the Handlin's Commonwealth," Rakove added, was the "distant objective" that lay "just over the horizon" of Bailyn's own explorations in the history of the long struggle between liberty and power. ${ }^{34}$

31. Oscar and Mary Handlin, The Dimensions of Liberty (Cambridge, Mass.: Harvard University Press, 1961); Louis Hartz, The Liberal Tradition in America: An Interpretation of American Political Thought since the Revolution (New York: Harcourt, Brace \& World, 1955). $101-5$

32. Bernard Bailyn, Origins of American Politics (New York: Alfred A. Knopf, 1968), 25,

33. Bernard Bailyn, "Shaping the Republic to 1760," in The Great Republic: A History of the American People, ed. Bailyn, et al. (Lexington: D. C. Heath and Co., 1977), 1:133-34, 188-97, 209-16.

34. Jack N. Rakove, "'How Else Could it End?' Bernard Bailyn and the Problem of Authority in Early America," in The Transformation of Early American History: Society, Authority, and Ideology, ed. James A. Henretta, Michael Kammen, and Stanley N. Katz (New York: Alfred A. Knopf, 1991 ), 54-55, quotation on 55. Only occasionally did Bailyn explicitly refer to the concept of 
Bailyn's characterization of the eighteenth-century provincial assemblies has yet to be subjected to a rigorous empirical test. It is, for example, by no means certain that, as Bailyn contended, the legislative mandate of the provincial assemblies actually exceeded that of the British Parliament. In addition, it is hardly self-evident that the provincial assemblies in the colonial era played a more conspicuous economic role than the state legislatures in the early republic. ${ }^{35}$ Such caveats, however, have done little to deter historians from asserting that, at some point in the nineteenth century, the American polity was transformed from an expansive and vigorous commonwealth into a minimalist, noninterventionist liberal state. The principal point of contention was the timing of this shift.

Consider, for example, Rowland Berthoff's Unsettled People (1971), one of the first major surveys of American social history to feature the theme of political declension. Berthoff, like Bailyn, was a student of Oscar Handlin, and he endorsed his mentor's thesis regarding the abdication of social responsibility. The "old commonwealth" of the colonial period - Berthoff echoed Handlin almost word-for-word - in which private enterprise was expected to be regulated for the "general welfare of the society," dissolved into the nineteenth-century liberal state, which "recognized no common social purpose greater than the sum of many private purposes of individual farmers, merchants, railroads builders, and industrial entrepreneurs." 36

Berthoff elaborated this view in 1973 in a widely cited essay that he coauthored with John M. Murrin, another historian who found the declension thesis compelling. During the first half of the nineteenth century, Berthoff and Murrin contended, "governmental regulation of the economy, hitherto accepted when required for the general welfare of the commonwealth, was progressively abandoned, first in practice and finally and principle." Before long, the government found itself "embarrassingly irrelevant" to the "social needs and concerns of America in general." Much of the problem could be traced to the continuing reliance of public figures on an increasingly anachronistic rhetoric that was obsessed with political corruption, a "disembodied Revolutionary rhetoric" that seldom bore any meaningful relation to social realities, and which made the "hard problems" of the day impossible to resolve. Not until after the Civil War, according to Berthoff and Murrin, would Americans begin to speak sensibly about the relationship of power,

the liberal state in his writings; see Bernard Bailyn, "The Central Themes of the American Revolution: An Interpretation," in Essays on the American Revolution, ed. Stephen G. Kurtz and James H. Hutson (Chapel Hill: University of North Carolina Press), 25, 30. Bailyn did, however, repeatedly refer to the concept in his teaching. Jack N. Rakove to Richard R. John, February 6 , 1996. Rakove has recently affirmed Bailyn's position: "The United States was little less a confederation when Madison died in 1836 than it had been when he set off for the Annapolis conference half a century earlier" (Rakove, Original Meanings: Politics and Ideas in the Making of the Constitution [New York: Alfred A. Knopf, 1996], 397 n.68).

35. Ibid., 212-13, 399-400 n.23. "For all that has been written about "the rise of the assembly' in America," Rakove observes, "its legislative output has not been rigorously analyzed" (ibid., 213).

36. Rowland Berthoff, An Unsettled People: Social Order and Disorder in American History (New York: Harper \& Row, 1971), 170. 


\section{RICHARD R. JOHN}

politics, and society. ${ }^{37}$ Historians of the early republic should, therefore, give up the study of governmental institutions and explore instead voluntary associations, private life, and the "things left out" of traditional accounts. ${ }^{38}$

Murrin devoted particular attention to the limited range of tasks the central government performed. Although contemporaries feared its rapid expansion, the central government was a "roof" without "walls," a "midget institution in a giant land." 39 What it lacked, in particular, were durable institutional links to the states. Critics who worried about the establishment of enduring bonds between the central government and local and regional elites had little to fear. In theory, the new government might be a "structural improvement" over the almost nonexistent administrative apparatus of the 1780s; in practice, it exercised few new substantive powers. When Americans declared their loyalty to the Constitution, they expressed less a genuine nationalist sentiment than a nagging fear that the Founders' order was so feeble that it could come crashing down at almost any time. ${ }^{40}$

By the 1970 s, the irrelevance of governmental institutions in the early republic had become something of a historiographical cliché. The 1790s, posited Gordon S. Wood in a leading textbook account in 1977 , were the "most awkward decade in American history, bearing little relation to what went on immediately before or after." Though the organizers of the dominant Federalist party hoped to establish a strong central government, they failed on virtually every count. Following the election of 1800 , the victorious Jeffersonian Republicans restored the government to the decidedly minor position it had enjoyed during the $1780 \mathrm{~s}$. "During the opening three decades of the nineteenth century" and particularly after Thomas Jefferson retired from the presidency in 1809 , the central government was "more feeble than at any other time in its national history." 41

Wood elaborated on his treatment of governmental institutions in his

37. Rowland Berthoff and John M. Murrin, "Feudalism, Communalism, and the Yeoman Freeholder," in Essays, 284, 278, 285-88. Berthoff and Murrin predicated their argument on the assumption that colonial America was, in fact, a monarchical society undergoing a "feudal revival" in which ties of personal dependence were becoming increasingly critical to one's political and economic standing. This conclusion has been challenged for Massachusetts by Richard L. Bushman, King and People in Provincial Massachusetts (Chapel Hill: University of North Carolina Press, 1985). Eighteenth-century Massachusetts, Bushman wrote, had a "monarchical culture" but was not a "monarchical society" (ibid., 85). Intriguingly, Bushman interpreted popular opposition to the British in the period after 1765 to the fear that the British were about to create a monarchical society in America (ibid., 207).

38. Rowland Berthoff, "Writing a History of Things Left Out," Reviews in American History 14 (March 1986): 1-16.

39. John M. Murrin, "The Great Inversion, or Court versus Country: A Comparison of the Revolution Settlements in England (1688-1721) and America (1776-1816)," in Three British Revolutions: 1641, 1688, 1776, ed. J. G. A. Pocock (Princeton, N.J.: Princeton University Press, $1980), 425$.

40. John M. Murrin, "A Roof without Walls: The Dilemma of American National Identity," in Beyond Confederation: Origins of the Constitution and American National Identity, ed. Richard Beeman, Stephen Botein, and Edward C. Carter, II (Chapel Hill: University of North Carolina Press, 1987), 346, 347.

41. Gordon S. Wood, "Framing the Republic, 1760-1820," in Great Republic, 1:341, 366. 
Pulitzer-Prize winning Radicalism of the American Revolution, a sweeping survey of the main contours of American public life in the early republic. During this period, Wood claimed, the traditional, hierarchical, monarchical, and deferential society of colonial America was transformed into the modern, egalitarian, democratic, and individualistic society that has characterized the United States to the present. The catalyst for this transformation was the American Revolution, the "most radical and most far-reaching event in American history." For Wood, the "real heroes" and "principal agents" of the age were not the Federalists, with their bold visions of governmental power, but the thousands of ordinary Americans, such as the backcountry Scotch-Irish immigrant William Findley, who challenged the conceit that there was a public good different from the private interests of the citizenry. ${ }^{42}$ For the first time in human history, Wood posited, the interests and prospects of ordinary people, their "pursuits of happiness," now became the goal of society and government. ${ }^{43}$ From Wood's standpoint, the Revolution was far more than a prelude to the establishment of an independent polity, as it had been, for example, for political historian Richard B. Morris, and cultural historian Linda K. Kerber. Rather, it was a large-scale social process that explained the "deep change" in the early republic's polity, culture, and economy. ${ }^{44}$

It has been noted that, in Radicalism, Wood underplayed several topics new social historians considered of considerable importance. He said, for instance, little about women and blacks. Yet, it is also true that Wood shared the new social historians' preoccupation with the social origins of political change. ${ }^{45}$ Like them, he took the coherence of American society more or less for granted and treated political developments as the products of antecedent social changes rooted ultimately in commercial expansion

42. Gordon S. Wood, "Equality and Social Conflict in the American Revolution," William and Mary Quarterly 3d ser., 51 (October 1994): 709, and id., "Interests and Disinterestedness in the Making of the Constitution," in Beyond Confederation, 69-109.

43. Gordon S. Wood, The Radicalism of the American Revolution (New York: Alfred A. Knopf, 1992), 8 .

44. Richard B. Morris, The Forging of the Union, 1781-1789 (New York: Harper \& Row, 1987); I.inda K. Kerber, "The Revolutionary Generation: Ideology, Politics, and Culture in the Early Republic," in New American History, 42; Wood, "Significance," 12-18. The phrase "deep change" was coined by David Hackett Fischer and can be traced back to his first book, The Revolution of American Conservatism: The Federalist Party in the Era of Jeffersonian Democracy (New York: Harper \& Row, 1965). Fischer deployed the concept to refer to the organizational changes in party behavior that political leaders set in motion with the victory of Thomas Jefferson in the election of 1800. "There is no period in American history" - Fischer wrote, with reference to the period between the election of 1800 and the War of 1812 - "in which fundamental change proceeded with greater power, speed, and effect" (ibid., 199).

45. Though Wood is hardly a behavioralist, in an early essay, he did praise what he termed a "behaviorist" perspective on the American Revolution. "Precisely because they sought to understand both the Revolutionary ideas and American society" - Wood observed, in referring to the scholarship of Merrill Jensen and his students - and notwithstanding their "crude conceptualizations," the "behaviorist historians of the Progressive generation" have "still offered us an explanation of the Revolutionary era so powerful and so comprehensive that no purely intellectual interpretation will ever replace it" (Wood, "Rhetoric and Reality in the American Revolution," William and Mary Quarterly 3d ser., 23 [January 1966]: 32). 


\title{
362 RICHARD R. JOHN
}

and demographic growth. ${ }^{46}$ To highlight the impersonal character of these changes, Wood sometimes resorted to the passive voice. Seldom did he treat major political developments as the deliberate design of purposeful individuals or groups and at no point did he locate the origins of these changes in the public sphere. ${ }^{47}$

Similar propositions have been advanced by historians outside of the Handlin-Bailyn orbit. For many, institutions were assumed almost reflexively to offer a less promising research agenda than the exploration of longterm patterns of social change. 48 "It was important" - wrote social historian Sean Wilentz, in 1982, in summarizing what remains today a widely held view - "not to subordinate the study of social structures and relations to the study of political institutions." 49 Most conceded, with Wood, that the Feder-

46. Although Wood, in Radicalism, relied on the concept of American society as a whole as his basic unit of analysis, he now questions the value of this concept for the colonial era. For early Americanists, Wood wrote in 1995 , the concept of society was no longer a viable organizing theme:

\begin{abstract}
So detailed has our understanding of the various bits and pieces of society become, so numerous are the monographs on this group or that local community, that historians have steadily lost confidence in their ability to conceive of early American society or even the society of a single colony as the proper area for study.
\end{abstract}

Wood's observation raises the issue, which no one has yet explored systematically, of how and why a relatively coherent American society eventually emerged. Gordon S. Wood, "A Century of Writing Early American History: Then and Now Compared; Or How Henry Adams Got it Wrong," American Historical Review 100 (June 1995): 694-95.

47. Several historians have touched on Wood's neglect of issues of agency. See, for example, Jack N. Rakove, "Gordon S. Wood, the 'Republican Synthesis," and the Path Not Taken," William and Mary Quarterly 3d ser., 44 (July 1987): 621. We ought to remember, Rakove contended, that republican politics were not primarily an exercise in semiotics but rather, and more elementally, a process by which "real historical actors" balanced and determined the conflicting claims that have "clamored for protection and promotion in every phase of our history" (ibid., 621).

48. Wood, "Significance," 4.

49. Sean Wilentz, "On Class and Politics in Jacksonian America," Reviews in American History 10 (December 1982): 52. Wilentz's theme was the social significance of the creation of mass parties that were anti-ideological in character. In keeping with this theme, Wilentz treated governmental institutions as more-or-less synonymous with political parties. The "ultimate problem" for political historians of the period, Wilentz wrote, was to determine the "social, ideological, and political contradictions" in electoral politics that led to the demise of the party system that had been organized around the Democrats and the Whigs (ibid., 59). See also his "Society, Politics, and the Market Revolution, 1815-1848," in New American History, 51-71. For an elaboration, with a particular focus on urban artisans, see Wilentz, Chants Democratic: New York City and the Rise of the American Working Class, 1788-1850 (New York: Oxford University Press, 1984).

The relationship between social circumstance and party formation is a theme of the two recent studies of Jacksonian politics: Harry L. Watson, Liberly and Power: The Politics of Jacksonian America (New York: Farrar, Straus, and Giroux, 1990), and Charles Sellers, The Market Revolution: Jacksonian America, 1815-1846 (New York: Oxford University Press, 1991). See also Melvyn Stokes and Stephen Conway, eds., The Market Revolution in America: Sorial, Political, and Religious Expressions, 1800-1880 (Charlottesville: University Press of Virginia, 1996). Both Watson and Sellers concentrate on the role of the so-called "market revolution" in shaping partisan loyalty in the decades following the War of 1812. For works that focus on the role of slavery in shaping party development, see William W. Freehling, The Road to Disunion: Secessionisls at Bay, 1776- 
alists tried to establish a strong central government, but that, overall, they contributed little of enduring value. ${ }^{50}$ Most contended that the mass of the citizenry had few expectations about governmental institutions and little interest in public affairs. Ordinary Americans, wrote religious historian Nathan O. Hatch, sought in the early republic "almost nothing from government institutions and almost everything from religious ones." 51 Even after the adoption of the federal Constitution, observed colonial historian Jack P. Greene, the central government lacked the necessary administrative capacity to shape events, while the mass of the citizenry remained preoccupied with private pursuits, much as their ancestors had been in the preRevolutionary era..$^{52}$

Particularly influential in tracing political developments to social causes have been legal historians. Few have gone quite so far as R. Kent Newmyer, who, in a recent essay, termed the early constitutional order a "Trojan Horse" of "radical social and economic transformation," set in motion by a rising class of capitalist entrepreneurs. ${ }^{53}$ Yet many shared his view that the early republic witnessed a revolution in legal rights that transformed the judiciary from a check on the governing class into an agent of economic development. ${ }^{54}$ Key figures in this tradition included Willard Hurst, who wrote an influential series of books and articles that contended that the nineteenth-century legal process encouraged the "release of energy" necessary for economic growth. ${ }^{55}$ Though Hurst's argument was carefully nu-

1854 (New York: Oxford University Press, 1990); Leonard L. Richards, "The Jacksonians and Slavery," in Antislavery Reconsidered: New Perspectives on the Abolitionists, ed. Lewis Perry and Michael Fellman (Baton Rouge: Louisiana State University Press, 1979), 99-118; and William J. Cooper, Jr., Liberty and Slavery: Southern Politics to 1860 (New York: Alfred A. Knopf, 1983).

50. See, for example, Joyce Appleby, Capitalism and a New Social Order: The Republican Vision of the 1790s (New York: New York University Press, 1984); John R. Nelson, Jr., Liberty and Property: Political Economy in the New Nation, 1789-1812 (Baltimore: Johns Hopkins University Press, 1987); and Gary J. Kornblith and John M. Murrin, "The Making and Unmaking of an American Ruling Class," in Beyond the American Revolution: Explorations in the History of American Radicalism, ed. Alfred F. Young (DeKalb, Ill.: Northern Illinois University Press, 1993), 27-79. For one of the most influential critiques of the role that earlier historians had assigned to the central government in nineteenth-century American life, see Thomas C. Cochran, "The 'Presidential Synthesis' in American History," American Historical Review 53 (July 1948): 748-59. See also Wallace D. Farnham, “'The Weakened Spring of Government': A Study in Nineteenth-Century American History," American Historical Review 68 (April 1963): 662-80.

51. Nathan O. Hatch, The Democratization of American Christianity (New Haven: Yale University Press, 1989), 14.

52. Jack P. Greene, Pursuits of Happiness: The Social Development of Early Modern British Colonies and the Formation of American Culture (Chapel Hill: University of North Carolina Press, 1988); id., Peripheries and Center: Constitutional Development in the Extended Polities of the British Empire and the United States, 1607-1788 (Athens, Ga.: University of Georgia Press, 1986).

53. R. Kent Newmyer, "John Marshall and the Southern Constitutional Tradition," in An Uncertain Tradition: Constitutionalism and the History of the South, ed. Kermit L. Hall and James W. Ely, Jr. (Athens, Ga.: University of Georgia Press, 1989), 115.

54. R. Kent Newmyer, "Harvard Law School, New England Legal Culture, and the Antebellum Origins of American Jurisprudence," Journal of American History 74 (December 1987): 820. See also Donald J. Pisani, "Promotion and Regulation: Constitutionalism and the American Economy," Journal of American History 74 (December 1987): 740-68.

55. Hurst's primary writings include Law and the Conditions of Freedom in the Nineteenth- 
anced, and while he accorded the legal system a good deal more autonomy than is often assumed, his work reinforced the widespread assumption that legal changes were best understood as a product of developments occurring outside of the political realm. ${ }^{56}$

Similar assumptions undergirded Morton J. Horwitz's Transformation of American Law, 1760-1860, a sweeping reinterpretation of legal change during the early republic in the industrializing Northeast. During this period, Horwitz argued, a small yet purposeful class of entrepreneurs collaborated with jurists, treatise writers, and other public figures to transform the legal order from a guardian of vested rights into an instrument of capitalist aggrandizement. Horwitz displayed considerable sympathy for the various groups who lost out in this process and roundly criticized the Handlins' for their failure to recognize the social costs this process entailed. Yet, like the Handlins, Horwitz regarded the legal innovations that he chronicled not as the product of pre-existing institutional arrangements, but, rather, of changes originating in the wider society.

Historians were by no means alone in downplaying the importance of governmental institutions in the early republic. Many political scientists (including several who were sharply critical of the behavioralist premises that had seeped into more than a few historical accounts), reached a similar conclusion. Some went so far as to deny that the United States in the early republic possessed a state at all. The absence of a state in the early republic, wrote political scientist Walter Dean Burnham in a widely cited letter, was the "chief distinguishing characteristic" of the American polity. 57 Many echoed Matthew A. Crenson's provocative claim that the initial bureaucratization of the central government was spurred not by the organizational imperatives of party strategists, as most scholars had previously assumed, but, rather, by social dislocations originating in the wider society. ${ }^{58}$

Century United States (Madison, Wisc.: University of Wisconsin Press, 1956); Law and Economir Growth: The Legal History of the Wisconsin Lumber Industry (Cambridge, Mass.: Harvard University Press, 1964); The Legitimacy of the Business Corporation in the Law of the United States, 1780-1970 (Charlottesville: University Press of Virginia, 1970); Law and Social Order in the United States (Ithaca, N.Y.: Cornell University Press, 1977); and "Old and New Dimensions of Research in United States Legal History," American Journal of Legal History 23 (1979): 1-20. For a bibliography of Hurst's writings, see Wisconsin Law Review (1980): 1131-32.

56. Scheiber, "Borderland," 744-56. See also Robert W. Gordon, "J. Willard Hurst and the Common Law Tradition in American Legal Historiography," Latw and Society 19 (Fall 1975): 9-55.

57. Cited in Morton Keller, "Social Policy in Nineteenth-Century America," in Federal Social Polig: The Historical Dimension, ed. Donald T. Critchlow and Ellis Hawley (State College, Pa.: Penn State Press, 1988), 102.

58. Matthew A. Crenson, The Federal Machine: Beginnings of Bureaucracy in Jacksonian America (Baltimore: Johns Hopkins University Press, 1975). For sympathetic glosses of Crenson's argument, see Michael Nelson, "A Short, Ironic History of American National Bureaucracy," Journal of Politics, 44 (August 1982): 760-62; James A. Morone, The Democratic Wish: Popular Participation and the Limits of American Government (New York: Basic Books, 1990), 87-94; Donald B. Cole, The Presidency of Andrew Jackson (Lawrence, Kans.: University of Kansas Press, 1993), 240; and Wood, Radicalism, 303-5. For a critique, see John, Spreading the News, esp. 79-83, 241-52, 337 n.164, 337 n.166, 337 n.168; Martin Shefter, Political Parties and the State: The American Historical Experience (Princeton, N.J.: Princeton University Press, 1994), 68; and Edward Pessen, rev: of Federal Machine, in Journal of Southern History 41 (November 1975), 553-54. 
Crenson's argument, long influential among historians and political scientists, looked to social circumstances to explain major innovations in governmental institutions, such as the introduction of bureaucratic procedures in national public administration. Crenson termed the bureaucratization of the civil government a Jacksonian innovation, inverting Leonard D. White's contention that the Jacksonians opposed bureaucratic expansion by subordinating the executive branch to the organizational imperatives of the mass party. ${ }^{59}$ Only in this way could the Jacksonians restore the public accountability that government officers had formerly taken for granted. In particular, Crenson contended, a general breakdown of social restraints during the 1820s left Jacksonian administrators such as Postmaster General Amos Kendall little choice but to devise new administrative methods that were ultimately codified in the Post Office Act of 1836, a centerpiece, in Crenson's view, of Jacksonian administrative reform. ${ }^{60}$

Even specialists in the history of Congress saw little reason to highlight the role of governmental institutions as such. "By any candid view" - wrote James Sterling Young, in a major study of the Jeffersonian Congress - the central government in the early republic was not "one of the important institutions in American society." 61 Young wrote in the 1960s, during the heyday of behavioralism. He found it reasonable to assert that the principal influences on congressional voting behavior were the bonds, rooted in local residential patterns, that tied individual Congressmen to each other. Congressmen voted by boardinghouse, Young concluded, rather than in response to constituent pressures, party loyalty, or the goals of the executive branch. Not until the rise of the Jacksonians, whose "functional significance" was to link the government with the citizenry in novel ways, would this situation change to a significant degree. ${ }^{62}$ Out of sight, Congress was out of mind. Young conceded that his study was not meant to be comprehensive, and that, in particular, he had not undertaken an intensive investigation of public policy. ${ }^{63}$ Given his behavioralist premises, it seems unlikely that such an investigation would have altered his conclusion in a major way. Having uncovered a correlation between social circumstances and voting behavior, he assumed that his work was done.

59. Crenson's analysis echoed the conclusions of historian Lynn Marshall, who propounded a similar thesis, with a similarly exalted view of the Post Office Act of 1836, in a major article that he published in the American Historical Review in 1967. Lynn Marshall, "The Strange Stillbirth of the Whig Party," American Historical Review 72 (January 1967): 445-68.

60. Much depends, of course, on one's definition of bureaucratization. Yet, if one identifies this process with formal job descriptions, meritocratic hiring and promotion procedures, and the cultivation of a sense of esprit de corps, then it is hard to avoid the conclusion that the Jacksonians slowed - and, to a significant degree, reversed - the largely successful bureaucratization of the central government that had been vigorously promoted in the 1820 s by energetic and ambitious administrators such as Postmaster General John McLean.

61. James Sterling Young, The Washington Community, 1800-1828 (New York: Columbia University Press, 1966), 27. See also Michael Nelson, "The Washington Community Revisited," Virginia Historical Revienv 61 (Spring 1985): 189-210; and Allan G. Bogue and Mark Paul Marlaire, "Of Mess and Men: The Boardinghouse and Congressional Voting, 1821-1842," American Journal of Political Science 19 (May 1975): 207-30.

62. Young, Washington Community, 35. 63. Ibid., xi. 


\section{RICHARD R. JOHN}

Young's disregard of policy helps explain why he had nothing to say about the large and growing influence during the 1820 s of federal-level administrators such as John C. Calhoun, William H. Crawford, and John McLean. In addition, it led him to exaggerate the isolation of national politics from the public-at-large. "There is no evidence in the records of the petitioning process of the Jeffersonian era" - wrote one historian, in a pointed reference to Young's claim to the contrary - "to suggest a feeling that the national government was distant and unapproachable." 64

Such caveats by no means reflect a consensus across the board. Consider, for example, Stephen Skowronek's brief but influential treatment, in Building a New American State, of American government in the early republic. Best known as a "new institutionalist" approach to American political development in the Gilded Age and Progressive era, Skowronek's study cogently disputed the notion that the early American republic lacked a state. "The early American state," he contended, "maintained an integrated legal order on a continental scale; it fought wars, expropriated Indians, secured new territories, carried on relations with other states, and aided economic development." 65 In addition, Skowronek effectively critiqued the behavioralists' belief that state building was a "natural and adaptive reaction" of governmental institutions to changing social circumstances. On the contrary, Skowronek contended that states changed, or failed to change, through political struggles rooted in and mediated by pre-established institutional arrangements. 66

But Skowronek also contended that the "great hallmark" of American political development in the early republic was "neatly summarized in the paradox that it failed to evoke any sense of a state." 67 In this period, Skowronek wrote, the American polity was a "state of courts and parties" in

64. Noble E. Cunningham, Jr., The Process of Government under Jefferson (Princeton, N.J.: Princeton University Press, 1978), 210, 303, quotation on 303.

65. Stephen Skowronek, Building a New Amerisan State: The Expansion of National Administrative Capacities, 1877-1920 (New York: Cambridge University Press, 1982), 19.

66. Ibid., viii, ix.

67. Ibid., 3, 5. Skowronek based his own account of these developments largely on the existing secondary literature, which, with few exceptions, reached a similar conclusion. See, for example, J. Rogers Hollingsworth, "The United States," in Crises of Political Development in Europe and The United States, ed. Raymond Grew (Princeton, N.J.: Princeton University Press, 1978), 163-95. Skowronek's characterization of the American policy in the early republic as a state of "courts and parties" has proved so influential among historians as well as political scientists that it is worth noting that, particularly for the period before 1829 , it rests on a thin empirical base. During the past few years, historians have documented numerous instances of administrative activism during the presidencies of James Monroe and John Quincy Adams. See, for example, Noble Cunningham, Jr., The Presidency of James Monroe (Lawrence, Kans.: University of Kansas Press, 1996), and Mary W. M. Hargreaves, The Presidency of John Quincy Adams (Lawrence, Kans.: University of Kansas Press, 1985). For a related discussion, see Charles C. Bright, "The State in the United States during the Nineteenth Century," in Statemaking and Social Movements: Essays in History and Theory, ed. Bright and Susan Harding (Ann Arbor, Mich.: University of Michigan Press, 1984), 123, 134-43. Skowronek himself recently amplified his account of national politics in this period to take into account this recent work. See, in particular, his suggestive survey of the Monroe and Adams administrations in The Politics Presidents Make: Leadership from John Adams to George Bush (Cambridge, Mass.: Harvard University Press, 1993), 86-127. 
which administrative bodies lacked the capacity to shape public affairs, jurists and party strategists directed the government, and Americans had yet to be imbued with the loathing of bureaucracy that many see as a ubiquitous feature of public life today. 68 This institutional and cultural setting, in turn, made the United States radically different from Europe, where politics revolved around a central administrative apparatus that was the cynosure of public affairs.

For a variety of reasons, a number of historians have found the above accounts of the role of governmental institutions in the early republic unpersuasive. Taken together, this scholarship can be termed the "new" institutionalism in history, to highlight its affinities with the new institutionalism in political science and to distinguish it from the "old" institutionalism in history and political science that flourished during the opening decades of the century. ${ }^{69}$ Thus far, the new institutionalism in history lacks the self-consciousness of its political science counterpart. Yet its leading practitioners share a common research agenda that focuses not only on discrete governmental institutions, such as courts, legislatures, or administrative agencies, but also on the configuration of institutions that gave the polity its distinctive character. For them - as for the polity-centered historical sociologist Theda Skocpol and the historical political scientists Stephen Skowronek and Karen Orren - governmental institutions are best conceived of as agents with wide ranging social and cultural effects. Often they focus not only on the goal-oriented activities of policymakers, but also on the unintended and often unforeseen consequences of the organizational network in which specific institutions are found. ${ }^{70}$

68. Skowronek, Building a New American State, 3-35.

69. Among historians, recognition of the new institutionalism as a distinct intellectual tradition dates back at least as far as 1965 , when John Higham drew attention to it in an influential study of the historical profession:

Deriving partly from studies in entrepreneurial and business history and partly from contemporary American sociology, this kind of history is less concerned with motives than with structure and process. ... Perhaps we may call this the new institutionalism; for it is bringing back to life a morphological study of organizations, now freed from the formalistic, evolutionary emphasis of nineteenth century scholarship. (John Higham, History: Professional Scholarship in America [Baltimore: Johns Hopkins Úniversity Press, 1965], 231)

70. Theda Skocpol, "Bringing the State Back In: Strategies of Analysis in Current Research," in Bringing the State Back In, ed. Peter B. Evans, Dietrich Rueschemeyer, and Theda Skocpol (Cambridge: Cambridge University Press, 1985), 21; Karen Orren and Stephen Skowronek, "Beyond the Iconography of Order: Notes for a 'New Institutionalism'," in The Dynamics of American Politics: Approaches and Interpretations, ed. Lawrence C. Dodd and Calvin Jillson (Boulder, Colo.: Westview Press, 1994), 311-30; and id., "Institutions and Intercurrence: Theory Building in the Fullness of Time," Nomos 38 (1996): 111-46.

For a related discussion, see Mark H. Leff, "Revisioning U.S. Political History," American 


\section{RICHARD R. JOHN}

Although the "new" and the "old" institutionalism share a common focus, they are quite different in method. Old institutionalists typically conceived of governmental institutions in a narrowly legalistic way and displayed a lively interest in the medieval and Teutonic origins of modern institutional forms. In addition, they neglected social and cultural themes, hardly surprising, since few historians had yet turned their attention in these directions. New institutionalists, in contrast, distinguish sharply between theory and practice and dwell less on institutional origins than on institutional effects. Though plainly influenced by, and, in some cases, elaborating upon, the rich and growing literature on culture and society, they break with these traditions by treating governmental institutions as agents of change. ${ }^{71}$

New institutionalist scholarship on the early republic challenges three common assertions about American political development. First, it disputes the claim that the government establishment of the 1780s had little enduring influence on American life. Second, it raises questions about the characterization of the American polity in the early republic - and especially in the period prior to the Jacksonian ascendancy - as a "state of courts and parties." And, third, it contests the notion that the major political developments in the early republic are best explained by antecedent social causes.

New institutionalists challenge these accounts by reframing the question. To compare the administrative apparatus that the Founders established with the administrative apparatus today, they contend, is an anachronistic exercise that is analogous to calling a horse a "wheel-less automobile." Far more sensible are comparisons between the central government in the early republic and the far weaker apparatus that existed prior to the framing of the federal Constitution. Policymakers in the early republic established the necessary institutional mechanisms to guarantee the prosperity and political stability of a burgeoning population that was scattered over a vast and expanding territory. In addition, they permitted free migration within the country (for everyone other than slaves), encouraged the rapid settlement of the transappalachian West, and hastened an unprecedented elaboration of the public sphere. None of these developments were even remotely conceivable prior to 1775 . Historians have been mistaken - declares Allan Kulikoff, in summarizing this view - to downplay the signifi-

Historical Review 100 (June 1995): 829-53; William E. Leuchtenberg, "The Historian and the Public Realm," American Historical Review 97 (February 1992): 1-18; id., "The Pertinence of Political History: Reflections on the Significance of the State in America," Journal of American History 73 (December 1986): 585-600; and Terrence J. McDonald, "The Burdens of Lrban History: The Theory of the State in Recent American Social History," Studies in American Political Development 3 (1989): 3-29.

71. For a recent appreciation of scholarship in the old institutionalist tradition, see "The Intellectual Legacy of the Johns Hopkins Seminary of History and Politics: Reconsidering the Geneology of the Social Sciences," Studies in American Political Development 8 (Fall 1994): $375-$ 408. See also David Brian Robertson, "The Return to History and the New Institutionalism in American Political Science," Social Science History 19 (Spring 1993): 36. 
cance of the establishment of the United States as a nation-state and the "nationalizing processes" this event set in motion. These "state functions," Kulikoff wrote, "inconceivable when the colonies were still tied to the British mercantile system, grew mightily in the new nation."72

Accompanying the new institutionalists' heightened appreciation for the central government is a renewed interest in the political legacy of the remarkable group of public figures - Federalist and Republican alike who dominated national politics in the years between 1787 and 1800. It is not my intention to summarize this scholarship, which ranges widely over topics in foreign as well as domestic affairs. ${ }^{73}$ Yet it is worth noting that, for several historians, including some who would probably reject the new institutionalist label outright, the Federalists' contributions are no less notable than those of their Republican antagonists. It is a mistake, argues Andrew R. L. Cayton, in a study of frontier Ohio, to characterize the Federalists as would-be aristocrats doomed to defeat in a democratic age. To be sure, the Federalists were not particularly likable men: "Their efforts to create a nation-state, with the attendant military and bureaucracy, offend the liberal and populist sensibilities of many late-twentieth century Americans." Still, they were men with power, "very real power, however limited it may seem in comparison with that of European states, and they used it to achieve very specific ends." 74 And their ideas "remained potent, largely because the growing complexity of [the] economy and society had convinced a significant group of men that an unregulated, liberal society would produce only chaos and degeneracy." 75

The new institutionalists' interest in the Founders' policy legacies is well illustrated by the revival of interest in the Northwest Ordinance. This legislation, passed in 1787 by the Continental Congress, provided for the orderly settlement of the territory north of the Ohio River on what was then the American frontier. Historians have long recognized its consequences to be far reaching, yet only recently have they systematically explored its political,

72. Allan Kulikoff, The Agrarian Origins of American Capitalism (Charlottesville, Va.: University Press of Virginia, 1992), 109. See also Merritt Roe Smith, "Army Ordnance and the "American system" of Manufacturing, 1815-1840," in Smith, Military Enterprise and Technological Change: Perspectives on the American Experience (Cambridge, Mass.: MIT Press, 1985), 40. Smith's essay includes a suggestive discussion of how governmental institutions in nineteenth-century America shaped cultural norms. See also his "Technological Determinism in American Culture," in Does Technology Drive History: The Dilemma of Technological Determinism, ed. Merritt Roe Smith and Leo Marx (Cambridge, Mass.: MIT Press, 1994), 1-35.

73. See, for example, Stanley Elkins and Eric McKitrick, The Age of Federalism: The Early American Republic, 1788-1900 (New York: Oxford University Press, 1993); and James Roger Sharp, American Politics in the Early Republic: The New Nation in Crisis (New Haven, Conn.: Yale University Press, 1993).

74. Andrew R. I. Cayton, “'Separate Interests' and the Nation-State: The Washington Administration and the Origins of Regionalism in the Trans-Appalachian West," Journal of American History 79 (June 1992): 66.

75. Cayton, Frontier Republic, 32, 131. See also id., "'Separate Interests' and the NationState," 39-67; id., "Land, Power, and Reputation: The Cultural Dimension of Politics in the Ohio Country," William and Mary Quarterly 3d ser., 47 (April 1990): 266-86; and Cayton and Peter S. Onuf, The Midwest and the Nation: Rethinking the History of an American Region (Bloomington, Ind.: Indiana University Press, 1990). 


\section{RICHARD R. JOHN}

economic, and cultural effects. ${ }^{76}$ By establishing procedures to grant equal status to the various political entities carved out of its domain - explains Peter S. Onuf, in a recent synthetic account - the Northwest Ordinance helped insure that the United States would not become a colonial power and that it would expand in an orderly way. "Drafted at a time of sectional division and constitutional crisis," the Ordinance "embodies a vision of a more harmonious, powerful, prosperous, and expanding union. ... The frontier would have to be transformed before the West could play its part in a revitalized union, a transformation that required the exercise of authority - to maintain order, protect legitimate land titles, and foster economic development - by a strong national government." 77 Though Onuf termed this vision liberal, it had little in common with the unregulated pursuit of private gain that later historians would identify with the liberal state. Rather, it was designed to involve thousands and ultimately millions of would-be landowners in a vast settlement scheme that policymakers assumed from the outset would serve the public good. ${ }^{78}$

Another policy legacy new institutionalists have probed is the role of the military in shifting the balance of power in the transappalachian West. The role of the army in the 1820 s and 1830 s in relocating the Civilized Tribes from the South Atlantic states to the west of the Mississippi is well known. No less important was its role during the 1800 s and 1810 s in weakening the hold of these tribes on their ancestral lands. Far more directly than land hunger, concludes Richard White, in a recent study of U.S.-Indian relations in the Great Lakes region, it was military exigency, in conjunction with diplomatic and political considerations, that destroyed the "middle ground" that prior to the War of 1812 made it possible for Indians, trappers, and settlers to coexist. ${ }^{79}$

Most new institutionalists endorse the observation of western historian Patricia Limerick that the central government has always played a vital role in the West. ${ }^{80}$ Yet they are sensitive to its role in more settled parts of the country as well. By establishing military armories in Springfield, Massa-

76. See, for example, Esmond Wright, Fabric of Freedom, 1763-1800, rev. ed. (1961; New York: Hill and Wang, 1978), 168.

77. Peter S. Onuf, Statehood and Union: A History of the Northwest Ordinance (Bloomington, Ind.: Indiana University Press, 1987), xiii.

78. For a related discussion, see James T. Kloppenberg, "The Virtues of Liberalism: Christianity, Republicanism, and the Ethics of Early American Political Discourse," Journal of American History 74 (June 1987): 9-33.

79. Richard White, The Middle Ground: Indians, Empires, and Republics in the Great Lakes Region, 1650-1815 (New York: Cambridge University Press, 1991).

80. Patricia Nelson Limerick, The Legacy of Conquest: The Unbroken Past of the American West (New York: W. W. Norton \& Co., 1987).

In the West . . it has been possible to see the future and to see that it works - sometimes. Heavy reliance on the federal government's good graces, the example of the West suggests, does expose the two principals to substantial risk - to inefficiency and mismanagement on the part of the benefactor and to resentment and discontent on the part of the beneficiaries. To a striking degree, the lessons of the problems of the American welfare state could be read in the nation's frontier past. (ibid., 89) 
chusetts, and Harpers Ferry, Virginia, explains Merritt Roe Smith, in his prize-winning study of early nineteenth-century military procurement, the central government helped lay the groundwork for mass production. ${ }^{81}$ Notwithstanding the vigorous resistance of artisans unaccustomed to the rigors of factory discipline, the armories enabled political entrepreneurs such as John $\mathrm{H}$. Hall to develop various machine tools and production techniques that made them a "keystone of modern interchangeable manufacture" and one of the principal American contributions to world technology in the nineteenth century. ${ }^{82}$ This achievement, Smith takes pains to stress, was spurred more by political than economic considerations and, in an age that preceded the coming of big business, lay beyond the capacity of any nongovernmental entity. "What the government provided," Smith explains, "was an ongoing bureaucratic organization within which the new technology - itself a bureaucratic phenomenon - could evolve." 83

A third institution that new institutionalists have explored is the postal system, which, in the early republic, quickly emerged as the linchpin of the postconstitutional communications infrastructure and the central administrative apparatus of the early American state. The role of the postal system in American public life in the early republic has been touched on by a number of historians, and is the theme of a monograph Richard R. John published in 1995. In 1828, the United States had 74 post offices for every 100,000 inhabitants; Great Britain, 17; France, $4 .{ }^{84}$ It is John's contention that this contrast can best be explained as a product of the commitment of American public figures to the creation of an informed citizenry, a goal that emerged in the year immediately following the adoption of the federal Constitution in 1787, and that marked a novel and in some ways radical departure from colonial and revolutionary era assumptions about the proper relationship between the government and the governed. ${ }^{85}$ Prior to

81. Historians of Great Britain have recently touched on broadly similar themes. See, for example, Patrick K. O'Brien, "Political Preconditions for the Industrial Revolution," in The Industrial Revolution and British Society, ed. O'Brien and Roland Quinault (Cambridge: Cambridge University Press, 1993), 124-55, and Peter Mathias, The First Industrial Nation: An Economi. History of Britain, 1700-1914, 2d (1969; London: Methuen, 1983), 31-75.

82. Merritt Roe Smith, Harpers Ferry and the New Technology: The Challenge of Change (Ithaca, N.Y.: Cornell University Press, 1977), 324.

83. Merritt Roe Smith, "Military Entrepreneurship," in Yankee Enterprise: The Rise of the American System of Manufactures, ed. Otto Mayr and Robert C. Post (Washington, D.C.: Smithsonian Institution Press, 1981), 95. For a related discussion of military influence in railroad management, see Charles F. O'Connell, Jr., "The Corps of Engineers and the Rise of Modern Management, 1827-1856," in Military Enterprise and Technological Change, 87-116.

84. John, Spreading the News, 5. See also Richard B. Kielbowicz, News in the Mail: The Press, Post Office, and Public Information, 1700-1860s (Westport, Conn.: Greenwood Press, 1989).

85. Only after the adoption of the federal Constitution, as J. R. Pole explains, would a "politics of trust," which presupposed that ordinary people possessed little knowledge about political matters, be supplanted by a "politics of vigilance" that invested the citizenry with the right to be more-or-less continuously informed about the affairs of state. The invention of this new vision of governance, Pole adds, was distinct from, and even more conceptually daring than, the institutionalization of the principle of political representation. "Neither political representation nor popular government was a new idea at the time of the American Revolution," Pole explains: "What was new in the politics of the time was the use of representation as a clearly defined institutional bridge between people and government. The two-way traffic over 


\section{RICHARD R. JOHN}

1787 , the public sphere remained patrimonial, the monopoly, as it were, of the tiny number of civic minded individuals who lived in close geographical proximity to the seat of power. After 1787 , no longer confined to a particular locality, it now spread itself throughout the vast territory over which the American government claimed to exercise its jurisdiction. ${ }^{86}$ By 1828 , the postal network was basically complete, an event that would have major consequences for American commerce and civic life. ${ }^{87}$

Congress institutionalized the creation of this "disembodied" public sphere with the Post Office Act of 1792, which subsidized the transmission of newspapers and other sources of information on public affairs, guaranteed the sanctity of personal correspondence, and created a mechanism for the rapid expansion of the postal network from the Atlantic seaboard to the transappalachian West. Though a few Federalists opposed certain provisions of this act, their obstructionism was far less significant than the widespread willingness of Federalists and Republicans alike to support such an unprecedented and potentially destabilizing expansion in public access to information about the affairs of state. ${ }^{88}$

the bridge was a traffic in knowledge. The men who devised the Constitution and the men who wrote the Federalist Papers had not yet anticipated that the principle of accountability would assume forms that would subject it to subject it to such intimate, yet public, investigation and control. . . Only through knowledge of the government of America could the people confide to it their confidence and trust." Jack R. Pole, The Gift of Government: Political Responsiblity from the English Restoration to American Independence (Athens, Ga.: University of Georgia Press, 1983), 140. For a related discussion, see Michael J. Lacey and Mary O. Furner, "Social Investigation, Social Knowledge, and the State: An Introduction," in The State and Social Investigation in Rritain and the United States, ed. Lacey and Furner (Cambridge: Cambridge University Press, 1993), 8.

86. On the role of public policy in the creation of the public sphere, see James W. Carey, Communication as Culture: Essays on Media and Society (Boston: Unwin Hyman, 1989), 1-9, and John, Spreading the News, chap. 2. See also id., "American Historians and the Concept of the Communications Revolution," in Information Acumen: The Understanding and Use of Knowledge in Modern Business, ed. Lisa Bud-Frierman (London: Routledge, 1994), 98-110. For a discussion of cultural values rather than institutional developments, see Richard D. Brown. The Strength of a People: The Idea of an Informed Citizenry in America, 1650-1870 (Chapel Hill: University of North Carolina Press, 1996); id., Knowledge is Power: The Diffusion of Information in Early America, 17001865 (New York: Oxford University Press, 1989); and Michael Warner, The Letters of the Republic: Publication and the Public Sphere in Eighteenth-Century America (Cambridge, Mass.: Harvard University Press, 1990). See also John L. Brooks, "Ancient Lodges and Self-Created Societics: Voluntary Association and the Public Sphere in the Early Republic," in Launching the 'Extended Reprublic': The Federalist Era, ed. Ronald Hoffman and Peter J. Albert (Charlottesville, Va.: University Press of Virginia, 1996), 273-377; and Thomas C. Leonard, News for All: America's Coming-of-Age with the Press (New York: Oxford University Press, 1995), chap. 1.

87. Though Tocqueville recognized the significance of voluntary associations in American public life, he overlooked the role of the central government in helping association organizers to spread their message. On this point, see Theda Skocpol, "The Tocqueville Problem: Civic Engagement in American Democracy," Social Science History (forthcoming).

Tocqueville's inadequate account of the central government, Tocqueville specialist James $T$. Schleifer has observed, was the "basic error" of his discussion of the nature and future of the American federation. Interestingly, Schleifer attributed this error to an uncritical reliance on political commentators such as Massachusetts jurist Joseph Story, who deliberately exaggerated the strength, ambition, and rights of the states. James T. Schleifer, The Making of Tocqueville's Democracy in America (Chapel Hill: University of North Carolina Press, 1980), 111.

88. The expansion of the postal network was greatly facilitated by the petition process, 
It is a truism of the new institutionalism in political science that institutions beget institutions; a case in point is the role of the postal system in spawning the mass party. ${ }^{89}$ The expansion of the postal system in the period prior to Jackson's victory in the election of 1828 was no less fundamental a precondition for the subsequent emergence of the mass political party than the extension of the suffrage, rapid improvements in the means of communication (which, of course, were also greatly facilitated by the postal system), or the social dislocations spawned by the uneven course of economic development. The existence of such a rich source of potential political patronage, mostly in the form of mail contracts and postmasterships, made the postal system an obvious target for ambitious public figures intent on building a political organization that would have a life of its own. Taking advantage of this opportunity, John McLean rose from political obscurity at the time of his appointment as postmaster general in 1823 to become a highly credible presidential contender by the time of his elevation to the Supreme Court in 1829.

The best overall index of the strength of governmental institutions in the early republic was the extent to which they bound together in a national community millions of Americans, most of whom would never meet in person. More than any other single factor, it was the existence of this civic infrastructure, in conjunction with the participation of ordinary Americans in public life that it helped to encourage, that differentiated the modern state that the federal Constitution brought into existence from the premodern state that it supplanted. ${ }^{90}$ In conjunction with the various other developments sketched in the previous paragraphs, this achievement helps explain how the United States could double its size, triple its population, and eliminate its national debt in the period between 1787 and 1835 without seeming to increase the size and scope of its central administrative apparatus. In no sense was this outcome an innocuous reflection of changes originating outside of the political realm. Rather, it was a product of deliberate political decisions that, however unpredictable their outcomes, enabled public officers to command the allegiance of a large and

another important element of the postconstitutional civic infrastructure. To establish a new post route, Congress required interested parties to petition Congress with a formal request. Thousands of these petitions have survived and can be sampled at the National Archives. Many were earnest, handwritten appeals. As such, they constitute eloquent testimony to the relevance of the government to everyday affairs and to the determination of the American people to secure the benefits that only the government could confer. For a more extended discussion of the petition process, see John, Spreading the News, 49-51, 173-74, 185-86, 189.

89. For a related argument, see Shefter, Political Parties, 68.

90. The role of the civic instrastructure in shaping political attitudes deserves more attention than it has thus far received. Political mobilization, as J.G.A. Pocock reminds us, can be a "most powerful engine in determining political and historical subjectivity." J.G.A. Pocock, "The Limits and Divisions of British History: In Search of the Unknown Subject," American Historical Review 87 (April 1982): 336. Such an inquiry would complement studies of the cultural consequences of market growth. See Thomas Bender, ed., The Antislavery Debate: Capitalism and Abolitionism as a Problem in Historical Imagination (Berkeley, Calif.: University of California Press, 1992); and Thomas L. Haskell and Richard F. Teichgraeber, III, ed., The Cullure of the Market: Historical Essays (Cambridge: Cambridge University Press, 1993). 
diverse population scattered over a geographically vast and culturally diverse domain.

New institutionalists have by no means confined themselves to exploring the role of the central government in American life. Equally important are a number of state and local studies that document how governmental institutions shaped social and cultural practices in realms as otherwise diverse as labor relations, citizenship, and family governance. ${ }^{91}$ These historians underscore the Handlins' and Hartz's contention that, in this period, it was often at the state and local level that governmental institutions had their most far-reaching effects. Yet they focus on practices that were regulatory rather than promotional, and that were decidedly more pervasive and enduring than the commonwealth tradition in Massachusetts or the mixed enterprise ideal in Pennsylvania.

Consider, for example, Hendrik Hartog's Public Property and Private Power, a richly detailed study of the legal evolution of the New York City corporate charter during the early republic. In the quarter century following the end of the War of Independence in 1781, Hartog contends, this corporation was transformed from a largely independent legal device into a "public entity" that was legally subordinate to the newly created state of New York. ${ }^{92}$ Hartog had originally assumed that city leaders resisted this change, since it greatly restricted their legal autonomy. But he quickly discovered that, on the contrary, they fully endorsed the expansive, republican rationale for policymaking at the state level that, following the war, became a defining feature of public life. For Hartog, a central element of this republican rationale was its emphatically public character. Only after the War of Independence, Hartog posits, and not before, would governmental power become the "public monopoly of a centralized state." ${ }^{93}$ The results were far-reaching. Soon the state government empowered the city of New York to perform a variety of tasks that had formerly fallen outside of its domain, ranging from the sweeping of streets and the confinement of pigs to the orderly platting of uptown Manhattan.

Accompanying this "radical new belief" that public power could be used to improve material conditions was the elaboration of a new public sphere of civic responsibility conceptually distinct from the private realm of individual aspiration. ${ }^{94}$ Support for this development was largely nonpartisan, and endorsed by both Federalists and Republicans. Hartog terms this out-

91. Christopher L. Tomlins, Law, Labor, and Ideology in the Early American Republic (Cambridge: Cambridge University Press, 1993); Linda K. Kerber, "The Paradox of Women's Citizenship in the Early Republic: The Case of Martin vs. Massachusetts," American Historical Review 97 (April 1992): 349-78; Michael Grossberg, Governing the Hearth: Law and the Family in NineteenthCentury America (Chapel Hill: University of North Carolina Press, 1985); and id., A Judgment for Solomon: The D'Hautville Case and Legal Experience in Antebellum America (Cambridge: Cambridge University Press, 1996).

92. Hendrik Hartog, Public Properiy and Private Power: The Corporation of the City of New York in American Law, 1730-1870 (Ithaca, N.Y.: Cornell University Press, 1983), 6.

93. Ibid., 264. 94. Ibid., 10. 
come "liberal" to underscore that, during this period, public figures established a rigid demarcation in the political theory of city government between the public and the private sphere, and a "fairly unambiguous acceptance" of the primacy of a market economy. In no sense were these developments carried over from the colonial era, as the Handlins had assumed. In New York state, the commonwealth vision rose and fell in the period prior to the break with the Crown. Hartog notes that,

It was then, in the years between the reception of the Montgomerie Charter [1730] and the coming of the American Revolution, that the corporation of the City of New York best approximated the commonwealth model of shared enterprise and blurred public and private spheres. ${ }^{95}$

Among the administrative means that Hartog regards as particularly important were the governmental mandates in Anglo-American common law that have come to be known as the police power. The goal of city leaders, Hartog explains, was to create a predictable and consistent environment within which the private market economy could flourish: "Planning and the exercise of police powers, for all their violations of purportedly vested private rights, were central for that role." 96

A considerably more detailed discussion of this common law heritage can be found in William J. Novak's People's Welfare: Law and Regulation in Nineteenth-Century America, a vigorously argued survey of the various regulatory responsibilities of nineteenth-century state governments. Unlike Hartog, and like the Handlins, Novak is more impressed by the cultural and institutional continuities in regulatory policy between the colonial era and the early republic than by the discontinuities set in motion by the War of Independence and the Constitution. Yet he pointedly questions the assumption, which goes back at least as far as Herbert Heaton, that these regulatory policies were somehow less coherent, capacious, or consequential than the promotional policies studied by the Handlins and Hartz. Far more important, and decidedly less "liberal" - that is, in the minimalist, noninterventionist, and laissez-faire sense - were a plethora of state and local regulations in realms as diverse as public safety, public health, and public morals. ${ }^{97}$

Novak's analysis of these regulations also leads him to question Richard L. McCormick's characterization of public policy in the early republic as primarily distributive. In particular, Novak faults McCormick for suggesting that government policymaking somehow evolved during the nineteenth century from distribution to regulation. At the state level, the government always exercised a wide range of regulatory powers. "The early republic," Novak explains, "far from being the formative era of an on-going tradition of vested rights, due process, and judicial review, gave rise to potent constitutional renderings of the public powers of the state." 98

The common law vision of a "well-regulated society" dominated American social and economic policymaking throughout the early republic. The

95. Ibid., 156-57. 96. Ibid., 153-54. 97. Novak, People's Welfare, 284, n.6.

98. William J. Novak, "Common Regulation: Legal Origins of State Power in America," Hastings Law Journal 45 (April 1994): 1096. 


\section{RICHARD R. JOHN}

legal order enshrined was not, as Hartog would have it, merely the "lesser and lighter" public half of a "perennial balancing act" between society and government, individualism and communitarianism, private interests and the people's welfare. Nor was it, as Berthoff and Murrin assumed, merely the "fading vestige" of feudalism, mercantilism, or civic republicanism. Rather, it was a "coherent, distinctive, and dominant legal-political discourse in nineteenth-century American life" whose "assumed and commonly accepted nature" only makes it that much harder to recognize. ${ }^{99}$ Implicit in Novak's account is a sweeping critique of the historians who have found the origins of the minimalist liberal state in the $1780 \mathrm{~s}$ (Onuf), around 1800 (Wood and Hartog), or during the Civil War era (Handlins and Hartz). Rather, Novak posits its emergence in the period after Reconstruction - just outside of the chronological scope of his study.

A final topic new institutionalists have investigated is the social and cultural effects of the configuration, or structure, of the institutions that made up the nineteenth-century American polity, including federalism and the separation of powers. ${ }^{100}$ Historians, of course, have long recognized that public figures devoted an enormous amount of time and energy to policing the boundaries between governmental jurisdictions. Often, however, they echoed progressive historians such as Frederick Jackson Turner and Charles Beard, who treated these efforts as little more than a thinly veiled rationalization for the competing claims of antagonistic social groups. ${ }^{101}$

The new institutionalists' sensitivity to the importance of structural considerations is evident in Colleen Dunlavy in Politics and Industrialism, a comparison of early nineteenth-century railroad policy in the United States and Prussia. From a financial standpoint, the various state governments in the United States were, at this time, more activist - or, conversely, less minimalist, or liberal - than the central government in Prussia. During the 1830s, the Prussian central government contributed no more than 7 percent of all the railroad capital in Prussia, while the various American states contributed around 45 percent. 102

To explain this contrast, Dunlavy distinguishes between political liberalism, which she associates with a broad suffrage and responsive legislatures, and economic liberalism, which she identifies with nonintervention and laissez-faire. In the 1830s, Dunlavy finds, the United States had a liberal polity and a nonliberal economy, while Prussia had a liberal economy and a nonliberal polity. For this reason, American legislators initially made a far

99. Novak, People's Welfare, 49.

100. Here new institutionalists build on the insights of older scholars such as Scheiber. See, in particular, Scheiber, "Federalism and the American Economic Order, 1789-1910."

101. Peter Onuf, "Reflections on the Founding: Constitutional Historiography in Bicentennial Perspective," William and Mary Quarterly 3d ser., 46 (April 1989): 345. "Could it be," Onuf asks rhetorically, "that the proper 'deconstruction' of the ratification debates lead back to federalism - and the problems of the union - and not into the deeper structure of American society?" (ibid., 357). See also id., The Origins of the Federal Republic: Jurisdictional Controversies in the United States, 1775-1787 (Philadelphia: University of Pennsylvania Press, 1983).

102. Colleen A. Dunlavy, Politics and Industrialization: Early Railroads in the United States and Prussia (Princeton, N.J.: Princeton University Press, 1994), 51-55. 
greater investment in the new technology. Not only did they possess more autonomy than their Prussian counterparts, but they lived in a more competitive institutional environment, making them more vulnerable to public pressure to speed the course of economic development. An analogous logic, Dunlavy argues, helps explain why, in the United States, engineering associations and railroad lobbying organizations remained highly decentralized, while in Prussia their counterparts were national in scope. By midcentury, however, with the expansion of the railroad beyond the geographical confines of individual states, the same structural features that had facilitated the rise of government economic activism hastened its demise. This was because public administrators now found themselves constrained by the constitutionally mandated division of authority between the central and state governments, and also by the relative weakness within the states of the executive in relation to the legislature.

This institutionalist perspective on government economic activism differs in subtle yet significant ways from the competitive interest-group model set forth a half century ago by George Rogers Taylor, as well as from the cultural approach of the Handlins and Hartz. ${ }^{103}$ For Dunlavy, and for the most conceptually ambitious of the new institutionalists, the key to American political development is to be found neither in the distinctiveness of American cultural values, nor in the interplay of its myriad interest groups, but, rather, in the structuring presence of the state. ${ }^{104}$ An institutionalist perspective, Dunlavy concludes, that is not sufficiently expansive to encompass the structure of national political institutions, will miss the "culprit" responsible for the "generally weak organization" of economic interests in the United States and for their comparative strength in Prussia. ${ }^{105}$

"What is needed," as one new institutionalist astutely has declared, "is not a political and institutional history that complements social and local history but a political and institutional history reconceptualized and reorganized in the light of what social and local historians have told us." 106 There is reason to suppose that at least some social historians are moving along a parallel course. "The best social history," as one leading social historian has recently observed, "attempts to integrate new research in institutional structures with consciousness and ideology in a way that creates under-

103. George Rogers Taylor, The Transportation Revolution, 1815-1860 (New York: Holt, Rinehart, \& Winston, 1951). For an appreciation of Taylor's achievement, see Harry N. Scheiber and Stephen Salsbury, "Reflections on George Rogers Taylor's The Transportation Revolution, 1815-1860: A Twenty-Five Year Retrospect," Business History Review 51 (Spring 1977): 79-89. For a critique, see Scheiber, "The Transportation Revolution and American Law: Constitutionalism and Public Policy," in Transportation and the Early Nation (Indianapolis, Ind.: Indiana Historical Society, 1982), 5-7. Notwithstanding Scheiber's admiration for Taylor, Scheiber faults him for exaggerating the role of social processes such as sectionalism in explaining opposition to public works, while downplaying the role of principled objections rooted in constitutional law (ibid., 5).

104. Dunlavy, Politics and Industrialization, 4. 105. Ibid., 196.

106. Andrew R. I. Cayton, "Comment," in author's possession, 7-8. 


\section{RICHARD R. JOHN}

standing of a broader political process and of the tensions that ultimately yield change." 107

Perhaps the best statement of the synthetic potential of the new institutionalism has been put forth by William $\mathrm{H}$. Freehling in a recent overview of scholarship on slavery and the Civil War. "Posterity," Freehling observes, "thinks of pre-Civil War government as quaint, small, and devoted to laissezfaire":

But just as Jackson's government moved Native Americans beyond the white man's frontier, so governments, state and national, aided the dispersal of the whites and the homogenization of the dispersed. The explosion of Americans across the continent required a Transportation Revolution and government helped provide it, building roads, financing canals, and enriching railroads with gigantic blocks of public land. The knitting of spread-out communities into a national culture required a Communications Revolution and government again helped provide it, commencing a telegraph line, establishing a far-flung postal network, giving printing bounties to national newspapers, and distributing congressmen's national speeches. Here, the political and social merged. The politics of moving blacks beyond the republic, the politics of moving Native Americans beyond the Mississippi, the politics of moving immigrants outside the voting booths, the politics of promoting and/or civilizing the westward movement - all this political history is important social history. ${ }^{108}$

It would be a major missed opportunity if historians interested in governmental institutions treated their subject as antagonistic to recent scholarship in social and cultural history. It would be equally unfortunate - though, one suspects, somewhat less likely, given recent scholarly trends - if they narrowed their focus to the central government at the expense of the states and localities. But until scholars bring these governmental institutions back in, it will be impossible to explain fully the rise of the mass party, the voluntary association, the national market, or a host of other major developments in American life.

Among topics worth exploring are public finance, taxation, and the administrative workings of state, city, and local government. ${ }^{109}$ Equally neglected is the evolving cultural and social significance of political patronage and its role in American electoral politics, particularly after the Federalist defeat in the election of 1800 . Such an inquiry might reveal that, long after 1800 - and contrary to the assertions of Berthoff, Murrin, and many recent historians - the specter of political corruption remained a realistic

107. Kessler-Harris, "Social History," 180.

108. William W. Freehling, The Reintegration of A merican History: Slavery and the Civil War (New York: Oxford University Press, 1994), 152-53.

109. On public finance, see Dall W. Forsythe, Taxation and Political Change in the Young Nation, 1781-1833 (New York: Columbia University Press, 1977); W. Elliott Brownlee, Federal Taxation in America: A Short History (New York: Cambridge University Press, 1996), 9-46; and Richard Sylla, John B. Legler, and John J. Wallis, "Banks and State Public Finance in the New Republic: The United States, 1790-1860," Journal of Economic History 47 (June 1987): 391-403. 
concern. ${ }^{10}$ By almost any conceivable measure, the patronage that public administrators and party organizers dispensed in the early republic was significantly greater than the patronage that their colonial predecessors had disbursed when the British American colonies remained under the Crown. Though patronage had lost many of its traditional ties to gentility, and was no longer a defining feature of personal identity, its disbursement remained a vital public task that affected the lives of thousands of Americans throughout the United States.

It should come as no surprise, then, that almost everyone who paid close attention to American politics in the early republic treated the disbursement of political patronage as a major concern. To this extent, as urban historian Terrence J. McDonald has aptly observed, the "sense of statelessness" that historically-minded political scientists such as Skowronek claim to have discovered in the early republic, "was to a great extent invented in mid-twentieth-century America." 11 In the early republic, the possibilities and the perils of governmental growth, far more than the hopes or fears inspired by commercial expansion, defined the parameters of public discourse. Not until later would corruption become a shorthand for capitalism, even though many historians have mistakenly conflated the two. ${ }^{112}$ In eighteenth-century Great Britain, as J.G.A. Pocock has observed, the "revolutionary class" was not the trading bourgeoisie, but soldiers, placemen, and financiers, all of whom were dependent in one way or another on the public purse. ${ }^{113}$ To an extent that few students of the early republic have fully realized, including Pocock himself, this also held for the United States in the early republic. ${ }^{114}$

Scholars would also do well to reconsider the history of internal improvements. For too long this topic has been hindered by the questionable assumption that public works projects lacked a broad popular mandate, and, thus, could be plausibly dismissed as class legislation for the favored few. "There was no spontaneous outpouring of shock or dismay," observes economic historian John Lauritz Larson, following President John Quincy

110. Paul Bourke and Donald DeBats, "Identifiable Voting in Nineteenth-Century America: Toward a Comparison of Britain and the United States before the Secret Ballot," Perspectives in American History 11 (1977-1978): 275. Since voting in the early republic was open, Bourke and DeBats note, even ordinary Americans had ample opportunity to monitor electoral irregularities at first-hand; Bourke and DeBats, Washington County: Politics and Community in Antebellum America (Baltimore: Johns Hopkins University Press, 1995).

111. Terrence J. McDonald, "Reply to Professor Katznelson," Studies in American Political Development 3 (1989), 54.

112. J.G.A. Pocock, The Machiavellian Moment: Florentine Political Thought and the Atlantic Republican Tradition (Princeton, N.J.: Princeton University Press, 1975), esp. 548.

113. J.G.A. Pocock, "Early Modern Capitalism - The Augustan Perception," in Feudalism, Capitalism, and Beyond, ed. Eugene Kamenka and R.S. Neale (London: Australian National University, 1975), 82. See also Pocock, "The Machiavellian Moment Revisited: A Study in History and Ideology," Journal of Modern History 53 (March 1981): 64; and id., "Between Gog and Magog: The Republican Thesis and the Ideologia A mericana," Journal of the History of Ideas 48 (April-June 1987): 343.

114. For a related discussion, see Daniel T. Rodgers, "Republicanism: The Career of a Concept," Journal of American History 79 (June 1992): 40. 
Adams's expansive justification for internal improvements in his first annual message, because this message "promised popular programs." 115 Given the popularity of public works spending, historians may well want to reopen the question of why these projects went down to defeat. One possible area of research would focus on the deliberate obstructionism of proslavery Southerners. Following the victory of Andrew Jackson in the election of 1828 and the subsequent stripping of the administrative capacity of the central government, policymakers lost the only plausible administrative mechanism that could conceivably have rid the country of slavery in a way short of war. Was this, one wonders, entirely a matter of chance? 116

In conclusion: While the new institutionalists have challenged a number of well entrenched notions about the relationship between politics and social change, their working assumptions are by no means altogether novel. Indeed, they share a certain unmistakable affinity with the world view of the public figures whose activities they recount. Prior to the $1880 \mathrm{~s}$, informed contemporaries took it for granted that politics best explained large-scale social processes such as the distribution of wealth. ${ }^{117}$ Only when historians subject the concept of society to the same degree of scrutiny that they have lavished on the concept of the state will it become possible to explore fully the cultural and institutional dimensions of American selfunderstanding in its formative years. ${ }^{118}$ At the very least, such a perspective ought to increase our appreciation of achievements, failures, and missed opportunities of the statesmen, party organizers, and ordinary men and women who together fashioned the governmental institutions that laid the foundation for the modern United States.

115. John Lauritz Larson, "Liberty by Design: Freedom, Planning, and John Quincy Adams's American System," in The State and Economic Knowledge: The American and British Experiences, ed. Mary O. Furner and Barry Supple (Cambridge: Cambridge University Press, 1990), 89-96, quotation on 95. On popular attitudes toward internal improvements, see also David J. Russo, "The Major Political Issues of the Jacksonian Period and the Development of Party Loyalty in Congress, 1830-1840," Transacions of the American Philosophical Society' 62, pt. 5 (1972): 3-51, esp. 28.

116. On this point, see also Robert P. Forbes, "Slavery and the Meaning of America, 18191833" (Ph. D. dissertation, Yale University, 1994). Forbes traces the injection of an explicitly racist rhetoric in to American political discourse to Jacksonian public figures such as Martin Van Buren, who used it to expand his political base.

117. James I.. Huston, "The American Revolutionaries, the Political Economy of Aristocracy, and the American Concept of the Distribution of Wealth, 1765-1900," American Historical Revieaw 98 (October 1993) : 1079-105. See also Richard L. Bushman, "This New Man': Dependence and Independence, 1776," in Uprooted Americans: Essays to Honor Oscar Handlin, ed. Bushman, et al. (Boston: Iittle, Brown, and Company, 1979), 93.

118. For a related discussion, see Charles Tilly, Big Structures, Large Processes, Huge Comparisons (New York: Russell Sage Foundation, 1984). 